\title{
The sea anemone Exaiptasia diaphana (Actiniaria: Aiptasiidae) associated to rhodoliths at Isla del Coco National Park, Costa Rica
}

Fabián H. Acuña ${ }^{1,2,5 *}$, Jorge Cortés ${ }^{3,4}$, Agustín Garese ${ }^{1,2} \&$ Ricardo González-Muñoz ${ }^{1,2}$

1. Instituto de Investigaciones Marinas y Costeras (IIMyC). CONICET - Facultad de Ciencias Exactas y Naturales. Universidad Nacional de Mar del Plata. Funes 3250.7600 Mar del Plata. Argentina, facuna@mdp.edu.ar, agarese@mdp.edu.ar, ricordea.gonzalez@gmail.com.

2. Consejo Nacional de Investigaciones Científicas y Técnicas (CONICET).

3. Centro de Investigación en Ciencias del Mar y Limnología (CIMAR), Ciudad de la Investigación, Universidad de Costa Rica, San Pedro, 11501-2060 San José, Costa Rica.

4. Escuela de Biología, Universidad de Costa Rica, San Pedro, 11501-2060 San José, Costa Rica, jorge.cortes@ucr.ac.cr

5. Estación Científica Coiba (Coiba-AIP), Clayton, Panamá, República de Panamá.

* Correspondence

Received 16-VI-2018. C Corrected 14-I-2019. Accepted 01-III-2019.

\begin{abstract}
Introduction: The sea anemones diversity is still poorly studied in Isla del Coco National Park, Costa Rica. Objective: To report for the first time the presence of the sea anemone Exaiptasia diaphana. Methods: Some rhodoliths were examined in situ in Punta Ulloa at $14 \mathrm{~m}$ depth, by SCUBA during the expedition UCRUNA-COCO-I to Isla del Coco National Park on $24^{\text {th }}$ April 2010. Living anemones settled on rhodoliths were photographed and its external morphological features and measures were recorded in situ. Results: Several individuals of $E$. diaphana were observed on rodoliths and we repeatedly observed several small individuals of this sea anemone surrounding the largest individual in an area (presumably the founder sea anemone) on rhodoliths from Punta Ulloa. Conclusions: The geographic distribution is extended as well as their bathymetric distribution from the intertidal to $14 \mathrm{~m}$ depth. The photographs provide evidence of clonal reproduction by pedal laceration.
\end{abstract}

Key words: Exaiptasia diaphana; subtidal; Punta Ulloa; Cocos Island; Eastern Tropical Pacific; Costa Rica.

Acuña, F. H., Cortés, J., Garese, A., \& González-Muñoz, R. (2020).The sea anemone Exaiptasia diaphana (Actiniaria: Aiptasiidae) associated to rhodoliths at Isla del Coco National Park, Costa Rica. Revista de Biología Tropical, 68(Suppl. 1), S283-S288.

The marine biodiversity of Isla del Coco has been the subject of scientific interest particularly for its biogeographic relevance and diversity. A list of published records of the marine organisms found in the area has been compiled by Cortés (2012). The growing interest in these investigations has been demonstrated in the recent International Symposium on Isla del Coco held in February 2018 at the University of Costa Rica. Although there have been many studies on different invertebrate groups, the sea anemones (order Actiniaria) diversity is still poorly studied. In fact, only two species of sea anemones have been recorded for the island, Telmatactis panamensis (Verrill, 1869) (Acuña, Cortés, \& Garese, 2012), and Anthopleura nigrescens (Verrill, 1928) (Acuña, Garese, Excoffon, \& Cortés 2013). During the expedition UCR-UNA-COCO-I to Isla del Coco National Park in April 2010, we sampled many sites including a rhodolith bed at $14 \mathrm{~m}$ depth, in Punta Ulloa. The rhodoliths constituted a benthic community dominated by free-living calcareous algae that can roll over the substrate pushed by the movement of water currents. Rhodoliths are one of the 
groups of algae with the widest geographical, climatic and bathymetric distribution and they are considered as bioengineers due to their propensity to construct a hard and complex substrate with hollows and sinuosities, which favors the settlement of numerous species and the development of various microhabitats (Foster, Amado-Filho, Kamenos, RiosmenaRodríguez, \& Steller, 2013; Mallol, Barberá, \& Goñi, 2015). The sea anemone Exaiptasia diaphana (Rapp, 1829) (= Exaiptasia pallida) was observed among the species associated to the rhodoliths. This paper documents the association and constitutes the first record of this actiniarian in the Isla del Coco National Park.

\section{MATERIAL AND METHODS}

Several rhodoliths were examined in situ in Punta Ulloa at $14 \mathrm{~m}$ depth, by SCUBA during the expedition UCR-UNA-COCO-I to Isla del Coco National Park on 24 ${ }^{\text {th }}$ April 2010. Living specimens of sea anemones settled on rhodoliths were photographed and its external morphological features and measures were recorded in situ. Identification of observed specimens were made following Fautin, Cleveland, Hickman, Daly, and Molodtsova (2007) and Grajales and Rodríguez (2014). The synonymies follow Grajales and Rodríguez (2014), and Daly and Fautin (2018).

\section{RESULTS}

Classification

Phylum Cnidaria
Sub Phylum Anthozoa
Clase Hexacorallia
Order Actiniaria
Suborder Enthemonae
Superfamily Metridioidea
Family Aiptasiidae
Genus Exaiptasia
Exaiptasia diaphana (Rapp, 1829)
(Figure 1A)

Synonymy: Actinia diaphana Rapp, 1829; Cribina diaphana: Deshayes \& MilneEdwards, 1840; Actinia elongata: Delle Chiaje, 1841; Adamsia diaphana: Milne-Edwards, 1857; Dysactis pallida: Agassiz in Verrill, 1864; Bartholomea tagetes: Duchassaing \& Michelotti, 1864; Bartholomea inula: Duchassaing \& Michelotti, 1864; Dysactis mimosa: Duchassaing \& Michelotti, 1864; Dysactis minuta: Verrill, 1867; Paranthea minuta: Verrill, 1868; Paranthea pallida: Verrill, 1868; Disactis mimosa [sic]: Duchassaing, 1870; Aiptasia saxicola: Andres, 1881; Aiptasia diaphana: Andres, 1883; Aiptasia Agassizii [sic]: Andres, 1883; Aiptasia inula: Andres, 1883; Aiptasia minuta: Andres, 1883; Aiptasia mimosa: Andres, 1883; Aiptasia tagetes: Andres, 1883; Aiptasia pallida: McMurrich, 1887; Aiptasia leiodactyla: Pax, 1910; Aiptasia insignis: Carlgren, 1941; Aiptasioides pallida: Stephenson, 1918; Aiptasiomorpha diaphana: Stephenson, 1920; Aiptasiomorpha leiodactyla: Stephenson, 1920; Aiptasia pulchella: Carlgren, 1943; Aiptasia californica: Carlgren, 1952; Aiptasiomorpha minuta: Uchida \& Soyama, 2001; Aipstasia pulchella [sic]: Reimer et al., 2007; Exaiptasia pallida: Grajales \& Rodríguez, 2014.

Characteristics of studied specimens of Exaiptasia diaphana: All taxonomic diagnostic features and measures observed in the specimens examined agree very well with those of the external anatomy described for Exaiptasia diaphana: oral disc from a few to $20 \mathrm{~mm}$ in diameter. Pedal disc regularly shaped, wider than column. Column elongated, smooth, not distinctly divisible into scapus and capitulum, translucent with scattered spots distally, mesenterial insertions visible as light lines in some individuals, whitish on the distal end (Fig. 1B). Oral disc brown, translucent, mouth white encircled with a brown ring, mesenterial insertions visible through oral disc as dark lines (Fig. 1C). Tentacles simple, smooth, long, slender, tapering toward tips, occurring only at margin and in variable in number, same color 

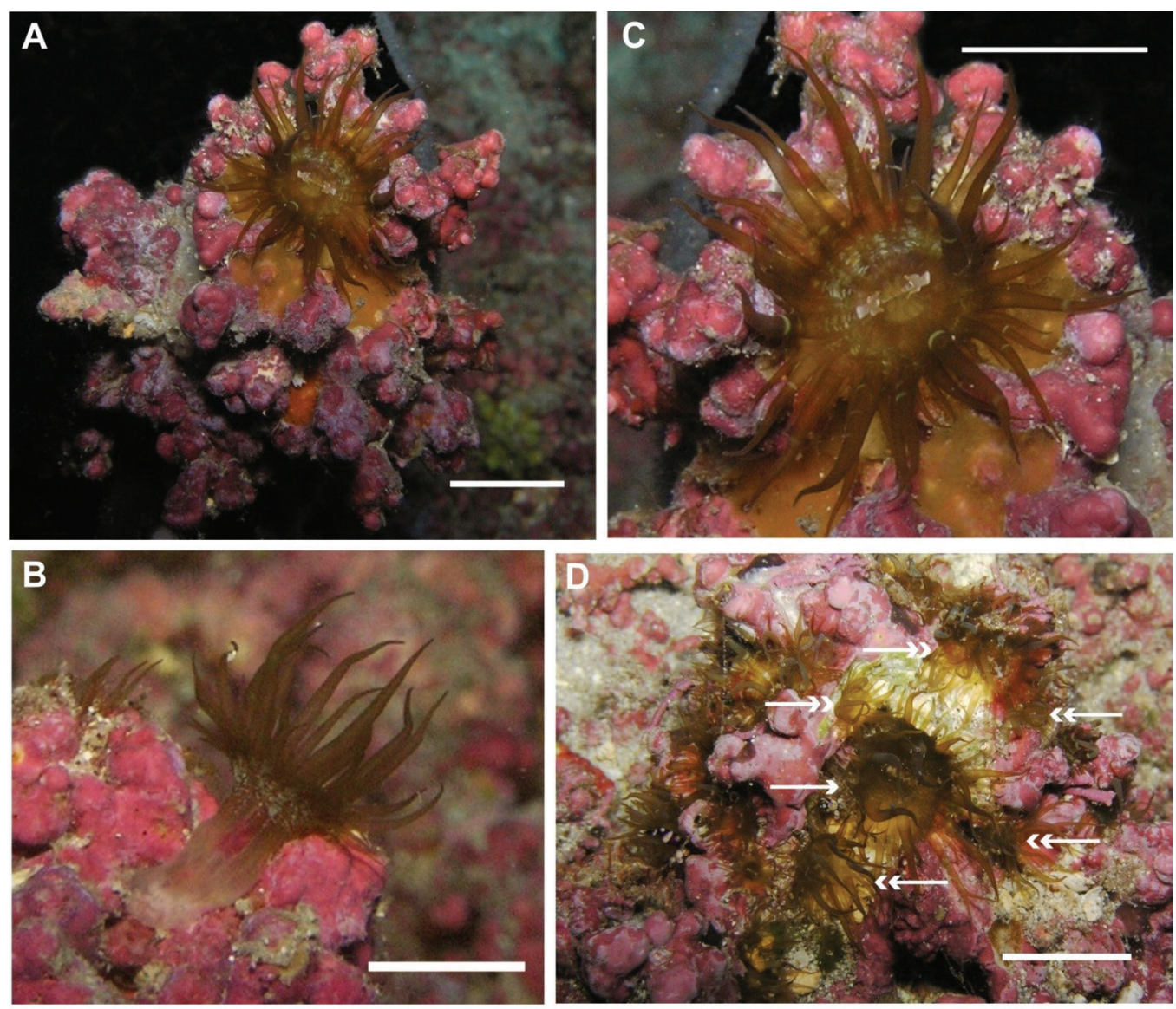

Fig. 1. A) Exaiptasia diaphana on a rhodolith in Punta Ulloa. B) Individual showing the translucent column with scattered spots distally. C) Expanded oral disc with tentacles (some with white around base and transverse bars), mouth and dark mesenterial insertions. D) A founder anemone $(\rightarrow)$ surrounded by some small individuals $(\rightarrow \rightarrow)$ possibly produced by clonal reproduction. Scale bars: $20 \mathrm{~mm}$.

than oral disc, some have white transverse bars around its base or on its oral face (Fig. 1C).

Natural history: Exaiptasia diaphana can reproduce asexually by pedal laceration, in which the animal is subdivided into generating clones that separate from small portions of the pedal disc (Clayton, 1985). We repeatedly observed several small individuals of $E$. diaphana surrounding the largest individual in an area (presumably the founder sea anemone) on rhodoliths from Punta Ulloa (Fig. 1D). Based on these observations, we suggest that smaller individuals were clonally produced by pedal laceration of the founder individual.

\section{Distribution other than Isla del Coco} National Park: This species has a widespread distribution, recorded almost worldwide along the northwestern Atlantic coast (Fautin, 2013), the Gulf of Mexico (e.g. Cary, 1906; Gunter \& Geyer, 1955) and the Caribbean Sea (e.g. Silbiger \& Childress, 2008; González-Muñoz, Simões, Sanchez-Rodriguez, Rodríguez, \& Segura-Puertas, 2012), the coast of Brazil in the southwestern Atlantic Ocean (e.g. Corrêa, 1964, 1973; Dube, 1983; Pires, Migotto, \& Marques, 1992; Castro, Echeverria, Pires, Mascarenhas, \& Freitas, 1995; Echeverria, Pires, Mederios, \& Castro, 1997; Zamponi, 1998; Farrapeira, Melo, Barbosa, \& Silva, 2007), the 
Galapagos Islands (Fautin et al., 2007), and in Australia. The distribution of this species was extended by Grajales and Rodriguez (2014) to the Mediterranean Sea and western Africa (geographic distribution of the former Aiptasia diaphana), the east and west Pacific coasts (e.g. California [geographic distribution of former A. californica], Japan and Hawaii [geographic distribution of former A. pulchella]), and Saint Helena Island (geographic distribution of former A. insignis). According to Grajales and Rodriguez (2014) Exaiptasia diaphana is a tropical and subtropical, shallow-water subtidal species, preferring calm and protected waters, found between $0-5 \mathrm{~m}$, although we extend this bathymetric distribution to $14 \mathrm{~m}$ depth in Punta Ulloa, Isla del Coco National Park.

\section{DISCUSSION}

Rhodoliths constitute particular microhabitats that host numerous species of invertebrates. Recent studies on rhodoliths in Isla del Coco have shown a great diversity of invertebrate taxa associated (one hundred and forty five taxa were found), among which the more diverse were polychaetes, arthropods, and mollusks, although crustaceans represent more than the half of the total number of organisms (Solano-Barquero, Sibaja-Cordero, \& CortésNúñez, 2018). However, other organisms, such as various groups of cnidarians have been recorded but not identified to the species level. In this work we report for the first time the presence of sea anemone Exaiptasia diaphana for Isla del Coco National Park associated with rhodoliths in a subtidal bed. This species belongs to the family Aiptasiidae whose taxonomy was recently revised by Grajales and Rodríguez (2014), including the erected new genus Exaiptasia.

The species E. diaphana was present in many rhodoliths from Punta Ulloa, reaching in many cases more than ten individuals per rhodolith (Fig. 1D), presumably as a result of clonal reproduction by pedal laceration. This type of asexual reproduction is characteristic of this species, even though longitudinal fission has also been reported (Clayton, 1985). The reproduction rate by pedal laceration is very high, so this species can easily become a plague to other organisms such as corals or sponges. In addition, this species reproduce sexually by the release of gametes, external fertilization and the formation of a free swimming planula larvae (Clayton, 1985). This mode of reproduction could facilitate its dispersal to other habitats including other rhodoliths in the same bed or even further away. The presence of anemone $E$. diaphana in rhodoliths has been reported (as Aiptasia californica) by King (2003) for other localities such as Bahía Concepción (Baja California, Mexico). King (2003) and others (Geller, Fitzgerald, \& King, 2005) performed interesting experiments involving rhodoliths' movement as an inducer of pedal laceration. Since rhodoliths and their associates are vulnerable to climate change and other anthropogenic disturbances (McConnico, Hernández-Carmona, \& Riosmena-Rodríguez, 2018), similar studies and others related to different aspects of anemone ecology in rhodoliths will allow a better understanding of the role of these algae and their importance in different marine ecosystems.

Ethical statement: authors declare that they all agree with this publication and made significant contributions; that there is no conflict of interest of any kind; and that we followed all pertinent ethical and legal procedures and requirements. All financial sources are fully and clearly stated in the acknowledgements section. A signed document has been filed in the journal archives.

\section{ACKNOWLEDGMENTS}

We are grateful to Jaime Nivia for collecting the rhodoliths during the dives and for images.

\section{RESUMEN}

La anémona de mar Exaiptasia diaphana (Actiniaria: Aiptasiidae) asociada a rodolitos en el Parque 
Nacional Isla del Coco. Introducción: La diversidad de anémonas de mar en el Parque Nacional Isla del Coco, Costa Rica, está aún poco estudiada. Objetivo: Reportar por primera vez la presencia de la anémona de mar Exaiptasia diaphana. Métodos: Algunos rodolitos fueron examinados in situ en Punta Ulloa a $14 \mathrm{~m}$. de profundidad mediante SCUBA durante la expedición UCR-UNACOCO-I al Parque Nacional Isla del Coco el 24 de abril de 2010. Especímenes vivos fijados sobre rodolitos fueron fotografiados y sus medidas y carácterísticas morfológicas externas fueron registradas in situ. Resultados: Varios individuos de E. diaphana fueron observados sobre rodolitos y observamos repetidamente pequeños individuos rodeando a un individuo mayor (presumiblemente la anémona fundadora) sobre rodolitos de Punta Ulloa. Conclusiones: La distribución geográfica de esta especie es extendida, como así también su distribución batimétrica desde el intermareal hasta los $14 \mathrm{~m}$ de profundidad. Las imágenes obtenidas aportan evidencia de reproducción clonal por laceración pedal.

Palabras clave: Exaiptasia diaphana; submareal; Punta Ulloa; Isla del Coco; Pacífico Tropical Oriental; Costa Rica.

\section{REFERENCES}

Acuña, F. H., Cortés, J., \& Garese, A. (2012). Ocurrence of the sea anemone Telmatactis panamensis (Verrill, 1869) (Cnidaria: Anthozoa: Actiniaria) at Cocos Island National Park, Costa Rica. Revista de Biología Tropical, 60 (Supplement 3), 201-205.

Acuña, F. H., Garese, A., Excoffon, A. C., \& Cortés, J. (2013). New records of sea anemones (Cnidaria: Anthozoa) from Costa Rica. Revista de Biología Marina y Oceanografia, 48(1), 177-184.

Andres, A. (1881). Prodromus neapolitanae faunae addito generalis actiniarium bibliographie catalogo. Mittheilungen aus der Zoologischen Station zu Neapel, 2, 305-309.

Andres, A. (1883). Le Attinie. Roma: Coi Tipi der Salviucci.

Carlgren, O. (1941). Papers from Dr. Th. Mortensen's Pacific Expedition 1914-16. LXX. The Actiniaria and Zoantharia of St. Helena. Videnskabelige Meddelelser fra Dansk naturhistorisk Forening $i$ Kjøbenhavn, 105, 1-20.

Carlgren, O. (1943). East-Asiatic Corallimorpharia and Actiniaria. Kungliga Svenska Vetenskapsakademiens Handlingar Serie, 20, 1-43.

Carlgren, O. (1952). Actiniaria from North America. Arkiv für Zoologi, Serie 2, 3, 373-390.

Castro, C. B., Echeverria, C. A., Pires, D. O., Mascarenhas, B. J. A., \& Freitas, S. G. (1995). Infralittoral hard bottom distribution of Cnidaria and Echinodermata in Arraial do Cabo, Rio de Janeiro, Brazil. Revista Brasileira de Biologia, 55 (3), 471-480.

Clayton Jr., W. S. (1985). Pedal laceration by the anemone Aiptasia pallida. Marine Ecology Progress Series, $21,75-80$.

Corrêa, D. D. (1964). Corallimorpharia e Actiniaria do Atlantico Oeste Tropical. São Paulo, Brasil: Universidade de São Paulo.

Corrêa, D. D. (1973). Sobre anémonas-do-mar (Actiniaria) do Brasil. Boletím de Zoologia e Biologia Marinha, 30, 457-468.

Cortés, J. (2012). Marine biodiversity of an Eastern Tropical Pacific oceanic island, Isla del Coco, Costa Rica. Revista de Biología Tropical, 60(Supplement 3), 131-185.

Cary, L. R. (1906). A contribution to the fauna of the coast of Louisiana. Gulf Biologic Station Bulletin, 6, 50-59.

Daly, M., \& Fautin, D. (2018) World List of Actiniaria. Exaiptasia diaphana (Rapp, 1829). World Register of Marine Species. Retrieved November 08, 2018 from http://www.marinespecies.org/aphia. php? $\mathrm{p}=$ taxdetails\&id=1264073.

Delle Chiaje, S. (1841). Descrizione e notomia degli animali invertebrati della Sicilia Citeriore osservati vivi negli anni 1822-1830. Napoli, Italy: C. Batelli e Comp.

Deshayes, G. P., \& Milne-Edwards, H. (1840). Revue et augmentée de notes présentant les faits nouveaux dont la science s'est enrichie jusqu'a ce jour. In Hist. Nat. des Animaux sans Vertébres, Présentant les caractères généraux Part. ces animaux, leur Distrib. leurs classes, leurs Fam. leurs genres, la Cit. des Princ. espèces qui s'y Rapp. 2nd ed. Paris, France: J.B. Baillière.

Dube, V. M. (1983). Contribuição ao estudo de anêmonasdo-mar do esta do da bahia. Natura, 83, 82-93.

Duchassaing, P. (1870). Revue des Zoophytes et des Spongiaires des Antilles. Paris, France: Chez Victor Masson et Fils.

Duchassaing, P., \& Michelotti, G. (1864). Supplément au mémoire sur les Coralliaires des Antilles. Turin, Italy: Imprimerie Royale.

Echeverria, C. A., Pires, D. O., Mederios, M. S., \& Castro, C. B. (1997). Cnidarians of the Atol das rocas, Brazil. Proceedings of the Eight International Coral Reef Symposium, 1, 443-446.

Farrapeira, C. M. R.; Melo, A. V. D. O. M., Barbosa, D. F., \& Silva, K. M. E. D. (2007). Ship hull fouling in the Port of Recife, Pernambuco. Brazilian Journal of Oceanography, 55(3), 207-221. 
Fautin, D. G. (2013). Hexacorallians of the World. Retrieved March 12, 2018 from http:/geoportal.kgs. $\mathrm{ku}$. edu/hexacoral/anemone2/index.cfm.

Fautin, D. G., Cleveland, P., Hickman, J. R., Daly, M., \& Molodtsova, T. (2007). Shallow-water sea anemones (Cnidaria: Anthozoa: Actiniaria) and tube anemones (Cnidaria: Anthozoa: Ceriantharia) of the Galápagos Islands. Pacific Science, 61(4), 549-573.

Foster, M. S., Amado-Filho, G. M., Kamenos, N. A., Riosmena-Rodríguez, R., \& Steller, D. L. (2013). Rhodoliths and rhodolith beds. Smithsonian Contribution Marine Science, 39, 143-155.

Geller, J. B., Fitzgerald, L. J., \& King, C. E. (2005). Fission in Sea Anemones: Integrative Studies of Life Cycle Evolution. Integrative and Comparative Biology, 45, 615-622.

González-Muñoz, R., Simões, N., Sanchez-Rodriguez, J., Rodríguez, E., \& Segura-Puertas, L. (2012). First inventory of sea anemones (Cnidaria: Actiniaria) of the Mexican Caribbean. Zootaxa, 3556, 1-38.

Grajales, A., \& Rodriguez, E. (2014). Morphological revision of the genus Aiptasia and the family Aiptasiidae (Cnidaria, Actiniaria, Metridioidea). Zootaxa, $3826(1), 55-100$

Gunter, G., \& Geyer, R. A. (1955). Studies on fouling organisms of the northwest Gulf of Mexico. Publications of the Institute of Marine Science (University of Texas), 4(1), 38-67.

King, C. (2003). Factors affecting the rate of asexual reproduction of Aiptasia californica. Master thesis, Moss Landing Marine Laboratories, Moss Landing, California.

Mallol, S., Barberá, C., \& Goñi, R. (2015). El maërl, un bioingeniero amenazado. Investigación y Ciencia, $465,44-45$.

McConnico, L. A., Hernández-Carmona, G., \& RiosmenaRodríguez, R. (2018). Nutrient production in rhodolith beds: impact of a foundation species and its associates. Marine Ecology Progress Series, 590, $53-66$

McMurrich, J. P. (1887). Notes on the fauna of Beaufort, North Carolina. Studies from the Biological Laboratory, Johns Hopkins University, 4, 55-63.

Milne-Edwards, H. (1857). Historie Naturelle des Coralliaires ou Polypes Proprement Dits, vol. 1. Paris, France: Librairie Encyclopédique de Roret.

Pax, F. (1910). Studien an westindischen Actinien. Zool Jahrbücher, 2, 157-330.

Pires, D. D. O., Migotto, A. E., \& Marques, A. C. (1992). Cnidários bentônicos do Arquipélago de Fernando de Noronha, Brasil. Boletim do Museu Nacional (Rio de Janeiro), NS Zoologia, 354, 1-21.
Rapp, W. (1829). Ueber die Polypen im Allgemeinen und die Actinien. Weimar, Germany: Grolsherzogl.

Reimer, J. D., Sinniger, F., Fujiwara, Y., Hirano, S., \& Maruyama, T. (2007). Morphological and molecular characterisation of Abyssoanthus nankaiensis, a new family, new genus and new species of deep-sea zoanthid (Anthozoa: Hexacorallia: Zoantharia) from a northwest Pacific methane cold seep. Invertebrate Systematic, 21, 255-62.

Silbiger, N. J., \& Childress, M. J. (2008). Interspecific variation in anemone shrimp distribution and host selection in the Florida Keys (USA): implications for marine conservation. Bulletin of Marine Science, 83(2), 329-345.

Solano-Barquero, A., Sibaja-Cordero, J., \& Cortés-Núñez, J. (2018). Organisms associated to rhodoliths in an oceanic island in the Eastern Tropical Pacific, Isla del Coco, Costa Rica. I Simposio Internacional sobre el Parque Nacional Isla del Coco y aguas adyacentes, Universidad de Costa Rica, San José, Costa Rica.

Stephenson, T. A. (1918). On certain Actiniaria collected off Ireland by the Irish Fisheries Department, during the years of 1899-1913. Proceedings of the Royal Irish Academy. Section B: Biological, Geological, and Chemical Science, 34, 106-164.

Stephenson, T. A. (1920). On the classification of Actiniaria. Part I. Forms with acontia and forms with a mesogleal sphincter. Quarterly Journal Microscopical Science, 64, 425-574.

Uchida, H., \& Soyama, I. (2001). Sea Anemones in Japanese Waters. Tokyo, Japan: TBS.

Verrill, A. E. (1864). Revision of the Polypi of the eastern coast of United States. Memoirs Boston Society of Natural History, 1, 1-45.

Verrill, A. E. (1867). Madreporaria. Commun Essex Institute, $5,33-50$.

Verrill, A. E. (1868). Synopsis of the polyps and corals of the North Pacific Exploring

Expedition, under Commodore C. Ringgold and Capt. John Rodgers, U.S.N., from 1853 to 1856 . Collected by Dr. Wm. Stimpson, Naturalist to the Expedition. Part IV. Actiniaria [First part]. Commun Essex Institute, $5,315-30$.

Verrill, A. E. (1869). Review of the corals and polyps of the west coast of America. Transactions of the Connecticut Academy of Arts and Sciences, 1(6), 377-558.

Verrill, A. E. (1928). Hawaiian shallow water Anthozoa. $B$ P Bishop Museum Bulletin, 49, 3-30.

Zamponi, M. O., Belém, M. J., Schlenz, E., \& Acuña, F. H. (1998). Distribution and some ecological aspects of Corallimorpharia and Actiniaria from shallow waters of the South American Atlantic coasts. Physis, $55,31-45$. 